\title{
Önállóságra éhezve. Az 1-es típusú diabetes mellitus és az anorexia nervosa együttes előfordulása egy serdülő leányban
}

\author{
Máté Orsolya ${ }^{1,2 *}$ - Ábrahám Ildikó dr. ${ }^{2 *}$ \\ Cserép Melinda ${ }^{2,3}$. Grundmann Lilla dr. ${ }^{2}$ - Lendvai Zsófia dr. ${ }^{2}$ \\ Pászthy Bea dr. ${ }^{2}$ - Tóth-Heyn Péter $\mathrm{dr} .{ }^{1}$
}

\begin{abstract}
${ }^{1}$ Semmelweis Egyetem, Általános Orvostudományi Kar, I. Gyermekgyógyászati Klinika, Diabétesz Osztály, Budapest ${ }^{2}$ Semmelweis Egyetem, Általános Orvostudományi Kar, I. Gyermekgyógyászati Klinika, Gyermek- és Ifjúságpszichiátriai Osztály, Budapest

${ }^{3}$ Semmelweis Egyetem, Általános Orvostudományi Kar, Magatartástudományi Intézet, Budapest
\end{abstract}

\begin{abstract}
Az 1-es típusú diabetes mellitus (T1DM-) betegek körében az evészavarok előfordulása az átlagpopulációhoz képest körülbelül kétszeresre tehető. Ez a komorbiditás különösen veszélyes mind a magas mortalitási rizikó, mind a súlyos szövődmények lehetősége miatt. Az evészavarban szenvedő, TIDM-mel élő gyermekek és fiatalok hatékony kezelése a diabetológusok, pszichiáterek, pszichológusok, nővérek és dietetikusok összehangolt munkájával valósítható meg. Közleményünkben egy 14,5 éves, T1DM-mel élö, anorexia nervosával diagnosztizált páciensünk multidiszciplináris terápiáját mutatjuk be, kiemelve a különböző szakemberek együttmúködésének főbb metszéspontjait. A szoros diabetológiai gondozással párhuzamosan az anorexia nervosa terápiájában a protokollok ajánlásaival megegyezően családterápiát és kognitív viselkedésterápiás elemekkel bővített egyéni terápiát alkalmaztunk. A terápiás folyamat összesen 18 hónapig tartott. Esetünk korábban le nem írt diabetológiai érdekessége, hogy a számottevő súlycsökkenéssel párhuzamosan betegünk inzulinigénye a töredékére csökkent, ami jelentős mértékben érintette a bazálisinzulin-szükségletet is. Orv Hetil. 2021; 162(33): 1341-1346.
\end{abstract}

Kulcsszavak: anorexia nervosa, l-es típusú diabetes mellitus, serdülőkor, multidiszciplináris terápia, családterápia, kognitív viselkedésterápia

\section{Starving for independence. Anorexia nervosa in an adolescent with type 1 diabetes}

The incidence of eating disorders is approximately twice as high in type 1 diabetes mellitus (TIDM) compared to the general population. Comorbidity is related to potentially severe organ complications and consequently higher mortality risk. The effective treatment of eating disorders in TIDM is provided by the teamwork of diabetologists, psychiatrists, psychologists, nurses and dietitians. The purpose of this paper is to present the multidisciplinary treatment of a 14.5-year-old adolescent with TIDM and diagnosed with anorexia nervosa, focusing on the cooperation of the professionals. In line with the current guidelines, both family therapy and cognitive behavioral therapy-informed individual psychotherapy were applied beside the strict diabetes control. Her therapy process lasted 18 months. The unusual diabetological aspect of our case is that the significant weight loss was associated with highly decreased insulin requirement affecting also the basal insulin requirements.

Keywords: anorexia nervosa, type 1 diabetes, adolescence, multidisciplinary treatment, family-based treatment, cognitive behavior therapy

Máté O, Ábrahám I, Cserép M, Grundmann L, Lendvai Zs, Pászthy B, Tóth-Heyn P. [Starving for independence. Anorexia nervosa in an adolescent with type 1 diabetes]. Orv Hetil. 2021; 162(33): 1341-1346.

(Beérkezett: 2020. november 10.; elfogadva: 2021. január 19.)

*Az első és a második szerző azonos mértékben járult hozzá a kézirat elkészítéséhez. 


\section{Rövidítések}

$\mathrm{BMI}=($ body mass index $)$ testtömegindex; T1DM = (type 1 diabetes mellitus) l-es típusú cukorbetegség

Az l-es típusú diabetes mellitus (T1DM) az egyik leggyakrabban előforduló, élethosszig tartó autoimmun anyagcserezavar gyermek- és serdülőkorban, melyben a hasnyálmirigy inzulintermelése megszűnik. Az evészavarok súlyos pszichoszomatikus betegségek, melyeket gyermekkorban a harmadik leggyakoribb krónikus betegségként tartanak számon [1]. A két kórkép közös előfordulásakor rendkívül fontos a korai felismerés és a különböző szakemberek (diabetológus, gyermekpszichiáter, egyéni és családterapeuták, dietetikus, osztályos kezelés esetén a nővérek) összehangolt munkája [2]. Ennek részleteibe enged bepillantást a 14,5 éves, T1DMmel élő, anorexia nervosával diagnosztizált páciensünk multidiszciplináris terápiájának bemutatása.

\section{Esetismertetés $^{1}$}

Tímea csendes, visszahúzódó serdülő leány, akinek 11 éves korában klinikánkon diagnosztizálták 1-es típusú cukorbetegségét. A TIDM prezentációjakor nem volt ketoacidosisa, a kivizsgálás során nem derült fény autoimmun társbetegségre. Kezdeti, viszonylag magas C-peptid-értéke $(2,21 \mathrm{ng} / \mathrm{ml})$ jó inzulinrezervet jelzett, a későbbi látványos csökkenés alapján azonban egyértelmú volt a cukorbetegség besorolása. Kezelését hagyományos humán inzulinrezsimmel (Actrapid, Insulatard) kezdtük el. Induló, 0,5 E/ttkg körüli inzulinigénye az első év folyamán alig változott. Három és fél év múlva, 14,5 éves korában gyakran előforduló hypoglykaemiás epizódokat, közel fél éve fennálló secundaer amenorrhoeát és restriktív étkezési magatartást észleltünk, jelentős mértékű fogyás mellett. A páciens körülbelül 14 éves korától az elöírt 140 g-os mennyiségnél tudatosan kevesebb szénhidrátot kezdett fogyasztani, ami napi inzulinigényének jelentős csökkenésében is tükröződött: a korábbi 50-60 egységről 6-11 egységre csökkent. Egy év alatt $10 \mathrm{~kg}$-ot fogyott, ebből az utolsó 3 hónapban 8 kg-ot vesztett.

Súlya a pszichológus bevonásakor $52 \mathrm{~kg}$ ( 50 percentilis), testmagassága $165,6 \mathrm{~cm}(50-75$ percentilis $)$, testtömegindexe (BMI) $19,1 \mathrm{~kg} / \mathrm{m}^{2}$ (25-50 percentilis) volt. A fogyást 12,5 , illetve 14 éves kora között jelentős, 15 kg-os súlygyarapodás elózte meg, akkor érte el addigi legnagyobb testsúlyát $(66,7 \mathrm{~kg}, 90-95$ percentilis; BMI: $24,73 \mathrm{~kg} / \mathrm{m}^{2}, 90-97$ percentilis). Az akkori hízást az inzulinigény számottevő emelkedése kísérte, legmagasabb adagja közel $1 \mathrm{E} / \mathrm{kg}$ volt (63 E/nap). Tímeánál erre az időszakra vonatkozóan retrospektíven depressziós epizód is valószínúsíthető, a túlevéseket, a diétahibákat közvetlen környezete előtt igyekezett titokban tartani. Ezt

${ }^{1}$ A páciens és szülei szóbeli beleegyezésüket adták esetük ismertetéséhez. követően édesanyja és kezelőorvosa is mérsékelt fogyásra biztatta. A fogyókúra mellett napi inzulinigénye intenzíven, rohamosan csökkenni kezdett, 6 hónap alatt 55 egységről 11 egységre. Kiemelendő, hogy az inzulinigény $80 \%$-os csökkenése hasonló arányban érintette a prandialis és a bazális inzulin adagjait, amit csak részben tudtunk a szénhidrátadagok jelentős restrikciójával magyarázni. A rendkívül alacsony bazálisinzulin-igény alapján felmerült a contrainsularis hormonok hiánya, az elvégzett vizsgálatok alapján azonban a pajzsmirigy és a mellékvesekéreg múködése, illetve a növekedési hormon szintjei a normális tartományban voltak. A TlDM ismert társbetegségére, a coeliakiára a kezdeti negatív eredményú szưrővizsgálatot követően a súlycsökkenés kapcsán ismét szürtük betegünket. Az aktuális negatív lelet alapján ki tudtuk zárni ezt a felszívódási zavart. A jelentős mértékű fogyás, a túlzott testmozgás, az amenorrhoea és az inzulinigény-csökkenés miatt Tímea kezelőorvosa evészavar gyanújával a Diabétesz Osztályon dolgozó pszichológushoz irányította a családot.

Tímea a pszichológussal való első találkozáskor felnőttes, körülményes szóhasználatú és szociális-kommunikációs készségeiben kissé eszköztelen, de kiemelkedő kognitív képességekkel rendelkező, perfekcionista serdülő benyomását keltette. A restriktív étkezési magatartás mellett az étkezéseket követő büntudat volt feltárható. Tímea a testével, testsúlyával való elégedetlenségét a vizsgálatok során negálta, de ennek hátterében markánsan felmerült a disszimuláció. Az elvárt testsúlygyarapodás kapcsán később egyértelmúvé vált a testképzavar. Hangulatát kiegyensúlyozottnak jellemezte, alvásával nem volt probléma. A kortársakkal való kapcsolatteremtési nehézségeit ő maga is megélte.

Anamnéziséből kiemelendő, hogy átlagos szociökonómiai státuszú, teljes családban él szüleivel és négy testvérével második gyermekként egy főváros környéki településen. A pater felsőfokú végzettségü, a mater fóállású édesanya. A családi anamnézis 2-es típusú diabetesszel mindkét ágon terhelt. Emellett az anyai ágon hangulatzavar és autizmus is megjelenik. Zavartalan, Streptococcus $B$-pozitív terhességből a 37 . hétre, természetes úton, 2500 gramm születési súllyal és $53 \mathrm{~cm}$-rel született, cardiorespiratoricus adaptációja zavartalannak bizonyult. Nyugodt csecsemő volt, 2,5 éves koráig részesült anyatejes táplálásban. Tímea fejlődéstörténetében szenzoros érzékenység, tartósabban fennmaradó, lábujjhegyen járás körvonalazódott. Ez utóbbi idegrendszeri éretlenségre utaló tünet gyakran megjelenik autizmusspektrum-zavarban. Társas készségeihez megemlítendő, hogy az óvodai, iskolai közösségbe nehezen illeszkedett be, többnyire egyedül tevékenykedett, barátai nem voltak, szülei magának való gyerekként beszéltek róla.

Tekintettel a korai anamnézisben felmerülő eltérésekre és a társas kapcsolódási nehézségekre, a pszichológus indokoltnak látta a kortársi közegben történő gyermekpszichiátriai osztályos megfigyelését. A multidiszciplináris szemléletben történő osztályos kivizsgálás során, bár 
bizonyos, az autizmusspektrum-zavarra jellemző tünetek megjelentek, Tímea a kórkép kritériumait nem merítette ki. A jelentős testsúlycsökkenés, a súlygyarapodástól való félelem, a testre fókuszáló önértékelés és a testképzavar alapján anorexia nervosát állapítottunk meg. Tímea akkor már 9 hónapja amenorrhoeás volt. A vizsgálatok a serdülőkori normatív krízisen túlmutató érzelemszabályozási zavart, szociális kapcsolódási nehezítettséget, perfekcionizmust, gondolkodásbeli rigiditást igazoltak.

A részletes diagnosztikát követően, a kognitív viselkedésterápiás folyamatot előkészítve, összegyűjtöttük az anorexia nervosára hajlamosító, azt kiváltó, fenntartó és protektív tényezőket, melyeket egyéni, családi és környezeti szinten elemeztünk (1. táblázat) [3].

\section{A terápia bemutatása}

A terápia alapjaként a serdülővel és szüleivel - a team minden tagjának jóváhagyásával - közösen előkészített és megfogalmazott terápiás szerződést kötöttünk. Az írásos megállapodás (testsúlyokhoz és testi-lelki állapotokhoz rögzítve) tartalmazta a gyógyuláshoz fontos lépéseket, az osztályos felvétel feltételeit, a sürgősségi ellátás kritériumait, az ambuláns ellátás alapjait. Meghatároztuk a közelebbi és távolabbi célokat, az ezekhez vezető konkrét lépéseket és feladatokat. Ez utóbbiak a terapeuták, a család, illetve a serdülő teendőit is magukban foglalják, felelős szerepet biztosítva a serdülő számá- ra. Az alábbiakban az egyéni és a családterápia fontosabb mozzanatait emeljük ki.

Tímea egyéni pszichoterápiája heti rendszerességgel a klinikán elindult. A serdülő és szülei a családterápiát először egy korábban általuk ismert pszichológusnál, a lakóhelyükön kezdték el. Egy újabb szomatikus krízis (a leány tovább fogyott, és kórházi felvételre került sor) kapcsán, a pszichiátriai kivizsgálást követő 4 . hónapban azonban biztonságosabbnak tartottuk, hogy minden terápia a klinikán belül történjen. A családterápiát T1DM-ben és evészavarban is jártas orvos családterapeuták vállalták.

\section{Az egyéni terápia}

A 18 hónapot átívelő, 57 ülésból álló terápia több szakaszra osztható. Az első időszakban (1-5. alkalom) a motivációra, a pszichoedukációra és a biztonságos terápiás keretek megteremtésére helyeztük a hangsúlyt. Ezt követően, a második szakaszban (6-25. alkalom) az anorexia elleni „küzdelem” volt előtérben, melynek során a terápiás hasítás, az anorexia megszemélyesítése (rajzban, párbeszédekben) effektív technikának bizonyult. Tímea gondolkodásában és viselkedésében markáns rugalmatlanságok, a „mindent vagy semmit” típusú kognitív torzítás volt detektálható, amelyek együttesen nehezítették a kitűzött testsúlycélok elérését. Ebben az időszakban Tímea a terápiás szerződésben meghatározott, kórházba való bekerülési testsúly környékén egyensúlyozott. Egy-

1. táblázat | Hajlamosító, kiváltó és protektív tényezők a cikkben bemutatott eset evészavarának kialakulásában

\begin{tabular}{|c|c|c|c|c|}
\hline & Hajlamosító tényezők & Kiváltó tényezók & Fenntartó tényezők / Betegségelőny & Protektív faktorok \\
\hline \multirow[t]{6}{*}{ Egyéni } & Perfekcionizmus & $\begin{array}{l}\text { A serdülőkor hormonális } \\
\text { változásai }\end{array}$ & $\begin{array}{l}\text { A kontroll megélése (étvágyra, } \\
\text { étkezésre, érzelmekre, családtagokra } \\
\text { vonatkozóan) }\end{array}$ & $\begin{array}{l}\text { A serdülő fokozott megfelelési } \\
\text { igénye, önismeretre és } \\
\text { változásra való nyitottsága }\end{array}$ \\
\hline & Kognitív rugalmatlanság & $\begin{array}{l}\text { Elakadás a serdülőkori } \\
\text { normatív krízisben }\end{array}$ & $\begin{array}{l}\text { Az éhezés kapcsán megélt disszocia- } \\
\text { tív állapot }\end{array}$ & $\begin{array}{l}\text { A konkrét gondolkodás ellenére } \\
\text { meglévő gazdag szimbolikus } \\
\text { belső tevékenység }\end{array}$ \\
\hline & Társas eszköztelenség & Beilleszkedési nehézségek & Az anorexia identitásformáló szerepe & Az egyéni figyelem preferenciája \\
\hline & $\begin{array}{l}\text { Érzelemszabályozási } \\
\text { nehézség }\end{array}$ & $\begin{array}{l}\text { A közelgő gimnáziumi } \\
\text { felvételivel kapcsolatos } \\
\text { szorongások }\end{array}$ & $\begin{array}{l}\text { Az inzulinigény csökkenése - } \\
\text { a TIDM-böl való gyógyulás tudat- } \\
\text { talan reménye }\end{array}$ & \\
\hline & Diabetesdiéta & $\begin{array}{l}\text { A testére vonatkozó } \\
\text { megjegyzések kapcsán átélt } \\
\text { elidegenedés }\end{array}$ & & \\
\hline & $\begin{array}{l}\text { A krónikus betegség } \\
\text { elfogadásának nehézsége }\end{array}$ & $\begin{array}{l}\text { Az egyetlen közeli barátnő } \\
\text { elvesztése }\end{array}$ & & \\
\hline \multirow[t]{5}{*}{$\begin{array}{l}\text { Családi és } \\
\text { környezeti }\end{array}$} & $\begin{array}{l}\text { Pszichiátriai betegségek } \\
\text { vonatkozásában terhelt } \\
\text { családi anamnézis }\end{array}$ & $\begin{array}{l}\text { Kortársak, testvérek } \\
\text { fogyókúrázása }\end{array}$ & $\begin{array}{l}\text { A családtagok fokozott figyelme, } \\
\text { gondoskodása }\end{array}$ & $\begin{array}{l}\text { A család érzelmi és megküzdési } \\
\text { erôforrásai }\end{array}$ \\
\hline & $\begin{array}{l}\text { Összemosott belső családi } \\
\text { határok }\end{array}$ & $\begin{array}{l}\text { A környezet fontos } \\
\text { személyeinek testalakjára } \\
\text { tett megjegyzései }\end{array}$ & $\begin{array}{l}\text { Új anorexiás osztálytárssal kötött } \\
\text { barátság }\end{array}$ & $\begin{array}{l}\text { A család változásra való } \\
\text { nyitottsága }\end{array}$ \\
\hline & $\begin{array}{l}\text { Fokozottan átjárható külső } \\
\text { családi határok }\end{array}$ & & & A humor mint megküzdés \\
\hline & Túlvédő anyai magatartás & & & Az új iskola befogadó közege \\
\hline & Túlkontrolláló nagyszülő & & & \\
\hline
\end{tabular}

T1DM = 1-es típusú cukorbetegség 
egy konkrét testsúlykilogramm említése is erős tiltakozást váltott ki a serdülőből, a szülők gyakran jelentkeztek kétségbeesve a terápiás ülések között a mérlegre állás körüli érzelmi kitörések és hangos szóváltások kapcsán. A klinikánkon párhuzamosan folytatott családterápia hozadéka, hogy a szülők Tímeába vetett bizalma növekedett, ami hozzájárult a leány önállóság- és kontrollérzésének megszilárdulásához. Ekkoriban kezdte el a gimnáziumot is. Ezt követően kétszer fordult elő, hogy kritikus (osztályos felvétel közelében lévő) testsúlyt ért el, mindkét esetben iskolai teljesítménynyomás mentén dekompenzálódott. Segített ezekben a krízisközeli helyzetekben, hogy - validálva érzéseit - megélhette a belé vetett bizalmat és támogatást. További hozadék, hogy az üléseken (25-38. ülés) megjelentek az evészavaron kívül más témák is: a szociális eszköztelenség, a rugalmatlanság, a kortársi kapcsolatokban megélt traumák, a saját érzések felismerése és a reálisabb énkép kialakítása. A terápia utolsó fázisában (38-57. ülés) eljutottunk a krónikus betegség elfogadásához és a kontroll kérdéséhez. Tímea megfogalmazta, hogy evészavara indulása óta kezeli önállóan cukorbetegségét. A lezáró szakaszban nagy hangsúlyt fektettünk a relapsusprevencióra.

\section{A családterápia}

A 8 családterápiás ülés 4 hónap alatt zajlott, a befejezést követően 1 alkalommal utánkövetéssel. 5 ülés történt Tímea és szülei részvételével, 2 alkalommal a teljes család volt jelen, 1 alkalommal a szülők szeparált ülése zajlott. Az utánkövetésen a szülők és a páciens volt jelen.

Tímea családjával gyorsan kialakult a jó terápiás kapcsolat. Ötgyermekes család, számos életciklus-feladattal, típusos, evészavarra jellemző strukturális nehézségekkel (a külső és belső határok átjárhatósága, összemosottság, 'overprotektivitás', rigiditás, a konfliktusmegoldás hiánya, a gyermek bevonása a szülők konfliktusaiba) $[4,5]$.

Ök magukat „hippi” családként definiálták, ezzel szimbolizálva már a bemutatkozáskor határtartási problémáikat. Kezdetben a kórházban is megfigyelt szülői túlóvásra helyeztük a hangsúlyt, elismerve azt, hogy két súlyos, életveszélyes betegség mentén a szülői kontroll érthető, sőt időnként életmentő. Egy aktuális helyzet kapcsán azonban (az édesanya próbálta elérni a hétvégi adaptációt) a szülőket direkt instrukciókkal sikerült rávezetni, hogyan támogassák Tímea önérvényesítését, hogyan segítsenek megküzdeni leányuknak az elkerülő viselkedéssel, képviselve ezzel a belé vetett bizalmat. Az anyai túlféltő múködésmód hátterének feltárását a családfa közös elemzése segítette. Az anyának az autizmussal élő öccse kapcsán megjelenő bűntudata, vesztesége megrendítő pillanata volt a terápiás folyamatnak. A testvérek bevonásával történt ülésen került felszínre egy fontos családi dinamika: két családtag közötti konfliktus csak a közös együttlétekben tud feloldódni, humorrá formálódni. Ehhez azonban mindenki jelenlétére szükség van, amit a kicsik élveznek, de a nagyobbaknak már sokszor terhes, köztük Tímeának is. A differenciálódás nehézsége ebben a családban mind hosszú, mind rövid távon markánsan megjelent: az évek óta zajló házfelújításra hivatkozva - az anorexiás családoknál oly gyakran látható problémával - az ajtók konkrét és szimbolikus hiányával szembesültünk. Míg a teljes család részvételével ebben a kérdésben direkt instrukciókkal haladtunk, addig a szülői alrendszerrel történő szeparált ülés során a helyzet mélyebb megértésére is sor került. Kapcsolatuk történetéről beszélgetve fogalmaztuk meg mindkettőjük közös tudattalan attitúdjét: a lakáson belüli ajtók hiánya, illetve a bejárati ajtó zárhatatlansága jelenti számukra a biztonságot, a szülőkben lévő gyermeki rész továbbélését, amire mindkettőjüknek elementáris igényük volt. A szülők megértették, hogy ez a bennük élő vágy a serdülőkorú gyerekeiknél a differenciálódás akadályává vált. A családterápiát lezártuk, a családdal probléma esetén történő jelentkezésben állapodtunk meg.

\section{Cukorbetegség az anorexia álarcában}

A diabetológus kezelőorvos a célsúly elérését követően közel 6 hónapon át azt tapasztalta, hogy a szénhidrátbevitel emelése mellett sem nőtt meg érdemben Tímea inzulinigénye, a magasabb inzulinadagok alkalmazása pedig hypoglykaemiát okozott. Amikor közelgett az új tanévkezdés, Tímea átmeneti, rövid ideig tartó restriktívebb étkezés után (melynek részben szorongás állt a hátterében) gyorsan tudta rendezni étkezését, azaz a szükséges kalória- és szénhidrátmennyiséget elfogyasztotta. A szülei ennek ellenére azt figyelték meg, hogy nem történt súlyemelkedés, sőt leányuk testsúlya 2-3 hét alatt egyre csökkent. A jelenség előtt mind Tímea, mind a család értetlenül állt. Szerződése értelmében osztályos felvételre került sor, ahol a team minden tagja vizsgálta a beteget. Részletes feltárást követően az evészavar talaján elindult manipulációkat elvetettük. Diabetológiai osztályos kivizsgálása és megfigyelése során derült fény arra, hogy inzulinigénye megnőtt, így a fogyás hátterében az elégtelen inzulinadagolás következtében jelentkező magas vércukorérték és glucosuria állhatott. A magasabb vércukorértékek mellett kezdetben osztályunkon is folytatódott a súlycsökkenés, majd az inzulinadagok 2-szeres, 8-ról 16 egységre történő emelése és a vércukrok normalizálása nyomán a serdülő súlya emelkedni kezdett. Két héten belül újra elérte célsúlyát.

A következő 6 hónapban a serdülőnél nem tapasztaltunk visszaesést, sem súlyában, sem pszichés állapotában. Egyéni pszichoterápiáját 2 hónapja lezártuk. A páciens inzulinigénye jelenleg is alacsony.

\section{Megbeszélés}

A legmagasabb mortalitással járó pszichiátriai kórkép diabetes mellitusszal való társulása nyilvánvalóan jelentősen rontja mindkét betegség prognózisát. Egy diétás kezeléstől nagyban függő anyagcserezavar egyensúlyának 
szinte semmi sem tesz rosszabbat, mint egy súlyos evészavar. Az esetismertetés egyik célja, hogy felhívjuk a figyelmet a T1DM-ben nagyobb arányban előforduló evészavartünetekre [6, 7]. A gyakoribb komorbiditás elsősorban a betegség jellegzetességeivel és a kezelés sajátosságaival hozható összefüggésbe [8].

A TIDM-páciensek körében előforduló evészavaros tünetek felismerése gyakran nehéz, amit - ahogy az esetleírásban is láthattuk - a páciensek disszimulációja részben magyaráz. Az anorexia nervosa kialakulásának első jele lehet az inzulinigény és a szénhidrátbevitel jelentős csökkenése. Az utóbbit a beteg hosszabb ideig titkolhatja, az előbbit azonban a kezelőorvos időben észlelheti, akár az eredeti inzulinadagok mellett jelentkező hypoglykaemiák révén. Fontos azonban megjegyeznünk, hogy a szubklinikai evészavar, amely nem a teljes kórképet, hanem egy-egy evészavaros tünet meglétét jelenti, ugyancsak jelentősen ronthatja a TIDM adherenciáját [8-10].

A két kórkép közös megjelenésének rizikófaktorai részben átfedést mutatnak a pszichoszomatikus zavarok kockázati tényezőivel (például a Tímeánál is kimutatható perfekcionizmussal). Rizikófaktort jelentenek továbbá a krónikus betegség terápiás sajátosságai, a T1DM kezeléséhez szükséges összetett és megterhelő öngondoskodási feladatok. Többek között idesorolható a szigorú diétás rezsim tartása, a szénhidrátszámolás, a testi paraméterekre való fokozott odafigyelés $[8,11-13]$. További rizikófaktor a T1DM diagnózisának időpontja. A 7-18 év közötti betegségkezdet hajlamosíthat evészavar kialakulására $[8,14]$. A serdülőkorban diagnosztizált cukorbetegség különösen megnehezíti a leválás folyamatát. A diagnózist követő első hetekben, hónapokban a fokozott szülői gondoskodás átszövi a mindennapokat (állandó szénhidrátszámolás, a reggeli korai ébresztésekhez való hozzászokás, éjjeli vércukormérések, éjjeli étkezések, a szülő telefonján megjelenő szöveti cukormonitor értékei), ami mind a szülőt, mind a serdülőt egy regreszszív állapot felé viheti. Az 'overprotektivitás' tartós fennmaradása nehezíti a serdülők megküzdését, akadályozza autonómiatörekvéseiket, hiszen a túlóvás mellett a fiatalok nem tanulnak meg bízni önmagukban, nem alakul ki az egészséges megküzdés, önértékelés. Ezt a szülők saját veszteségei, transzgenerációs mintái (ebben az esetben az édesanya ágán megjelenő, autizmussal élő testvér kapcsán feléledő szorongás) gyakran tovább terhelik.

A serdülőkor lélektani változásai szorosan összefüggenek a hirtelen történő testi változásokkal. A cukorbetegség esetén ezek még kifejezettebbek lehetnek. A diabetes kialakulásának kezdetén megjelenő, abszolút inzulinhiánnyal magyarázható látványos fogyás, illetve az ezt követő, inzulinkezeléshez kötődő súlygyarapodás (Tímeánál másfél év alatt $15 \mathrm{~kg}$ ) az arra vulnerábilis személyeknél evészavart indíthat el $[8,15,16]$.

A terápiás folyamat kapcsán fontos kiemelni a multidiszciplináris munkacsoportban történő komplex kezelést [2], mely magában foglalja a közös edukatív meg- beszéléseket, viziteket, esetmegbeszélőket. A korai felismerést és a korai kezelésbe vételt egyaránt segíti a rendszeres, elérhető pszichológusi jelenlét a diabetológiai centrumokban, amit a nemzetközi irányelvek is hangsúlyoznak [2]. Klinikánkon 2014 óta pszichológus is állandó tagja a Diabétesz Osztályon zajló teammunkának. Amennyiben nincs lehetôség rutinszerü pszichológiai vizsgálatra a T1DM-betegek körében, akkor a rizikófaktorok komplex kiértékelése jelenthet iránymutatót a célzott pszichológiai/pszichoterápiás segítség indikálásához. Míg komorbiditás nélkül fennálló anorexia nervosa esetén - ameddig a testi-lelki állapot azt biztonsággal lehetővé teszi - az ambuláns ellátási forma javasolt, addig T1DM és anorexia társulásakor elakadások, relapsusok kapcsán osztályos kezeléseket ajánl a szakirodalom [17]. $\mathrm{Az}$ állapotrosszabbodás hátterének pontos tisztázása, a pszichés és a szomatikus tényezők értékelése ugyancsak a team közös feladata.

Az osztályos kezelést indokolttá teszi a két kórkép együttes megjelenésének számottevő diabetológiai kockázata is. A betegünk esetében észlelt, jelentősen csökkenő inzulinigényhez való adaptáció otthoni körülmények között valószínúleg nem várható, így a súlyos hypoglykaemiák kockázata jelentősen megnő. A súlyvesztés és az inzulinigény-csökkenés lehetséges organikus okainak feltárásakor hangsúlyos szempont a T1DM autoimmun társbetegségeire való ismételt szúrés. A bemutatott kórtörténetben is kiemelendő a coeliakia, a pajzsmirigyfunkció-zavar és a hypadrenia kizárásának fontossága. A betegünknél tapasztalt prandialisinzulin-igény csökkenést könnyen magyarázhatjuk a minimálisra redukált szénhidrátbevitellel. Nehezen magyarázható azonban az, hogy szinte megszúnt a bazálisinzulin-szülkséglet is. Korábban ezt a jelenséget nem írták le.

Fontos felhívni a figyelmet arra, hogy a szénhidrátadagok lassú emelése mellett követni kell az inzulinadagok elvárt növekedését. Ellenkező esetben a megjelenő hyperglykaemia és glucosuria részben hatástalanná teszi a szénhidrátfogyasztást, és ahogy betegünknél szintén észleltük, ez súlycsökkenéshez vezethet. Feltételezhető, hogy az anorexiás betegeknél leírt tubularis funkciózavar részeként a glükóz veseküszöbe alacsonyabb, így viszonylag alacsonyabb vércukorértékeknél megjelenik a vizelettel történő glükózvesztés [18].

Klinikánkon a TIDM és az evészavarok együttes előfordulásakor pszichoterápiás szempontból - a bizonyítékokon alapuló terápia jegyében - elsődlegesen családterápiát végzünk $[5,19]$, melynek fontos kiegészítője a kognitív viselkedésterápiás eszközöket tartalmazó egyéni terápia.

\section{Következtetés}

Az eset kapcsán szerzett tapasztalataink megerősítik, hogy a családterápia a leghatékonyabb pszichoterápiás módszer a két kórkép közös megjelenésekor [4, 5, 19]. Ezt mutatja, hogy Tímea súlygyarapodása egyértelmúen 
a családterápia elkezdését követően indult meg. Korábban nem publikált felismerés az eset kapcsán, hogy a restriktív evésből következő inzulinigény-csökkenés tudattalan betegségelőnyként jelenhet meg: „Fogyással nemcsak sovány, figyelemre méltó és szerethető leszek, hanem még a cukorbetegségemból is meggyógyulhatok." Ennek az egyéni terápiában történó átdolgozása nemcsak az anorexiából való gyógyulás, hanem a T1DM elfogadásának is egyik fontos lépésévé vált. Újonnan megfogalmazott megfigyelésünk az is, hogy az étkezési inzulinadagoknak a szénhidrátbevitel jelentős restrikcióját kísérő $80 \%$-os csökkenése mellett hasonló arányban változott a bazálisinzulin-igény is, ami az alapanyagcsere jelentős lassulására utalhat. A TIDM első éveiben a kezdeti alacsony inzulinigény jellemző módon emelkedik, ami különösen igaz a serdülés éveire. Az inzulinigényben jelentkező jelentős csökkenést tehát mindenképpen komoly figyelmeztető jelnek kell tekinteni, amelynek hátterében az evészavar mellett a contrainsularis hormonok hiánya is állhat.

Írásunkkal hangsúlyozni szeretnénk a T1DM és az evészavar közös megjelenésére vonatkozó interdiszciplináris irányelv kidolgozásának szükségességét. Ezenkívül fontosnak tartjuk a minél korábbi evészavar-diagnózis felállítását és az evészavar-veszélyeztetettség felismerését, melyhez diabetesspecifikus evészavar-kérdőív [20] magyar nyelvre való adaptálása és validálása egységes módszertani hátteret jelenthetne.

Anyagi támogatás: A kézirat elkészítése és a kapcsolódó kutatás anyagi támogatásban nem részesült.

Szerzôi munkamegosztás: M. O., Á. I., Cs. M., T.-H. P.: A kézirat megszövegezése. M. O., Á. I., Cs. M., G. L., L. Zs., T.-H. P.: A szakirodalom áttekintése. M. O., Á. I., Cs. M., P. B.: A szöveg áttekintése, a táblázat szerkesztése. A cikk végleges változatát valamennyi szerző elolvasta és jóváhagyta.

Érdekeltségek: A szerzőknek nincsenek érdekeltségeik.

\section{Irodalom}

[1] Fisher M. Treatment of eating disorders in children, adolescents, and young adults. Pediatr Rev. 2006; 27: 5-16.

[2] Kakleas K, Kandyla B, Karayianni C, et al. Psychosocial problems in adolescents with type 1 diabetes mellitus. Diabetes Metab. 2009; 35: 339-350.

[3] Perczel-Forintos D. Behavioral diagnostics. In: Perczel-Forintos D, Mórotz K. (eds.) Cognitive behavioral therapy. 4th revised and expanded edition. [Viselkedésdiagnosztika. In: PerczelForintos D, Mórotz K. (szerk.) Kognitív viselkedésterápia. 4. átdolgozott és bővített kiadás.] Medicina Könyvkiadó, Budapest, 2019; pp. 61-80. [Hungarian]

[4] Túry F, Pászthy B. Family-based treatment for eating disorders in light of recent data. In: Túry F, Pászthy B. (eds.) Eating disorders and body-image disorders. [Az evészavarok család- terápiája az újabb adatok fényében. In: Túry F, Pászthy B. (szerk.) Evészavarok és testképzavarok.] Pro Die Kiadó, Budapest, 2008; pp. 437-449. [Hungarian]

[5] Túry F, Pászthy B. Common traps in family-based treatment for eating disorders. In: Túry F, Pászthy B. (eds.) Current issues in the psychotherapy of eating disorders. [Családterápiás csapdák az evészavarok kezelésében. In: Túry F, Pászty B. (szerk.) Az evészavarok pszichoterápiájának aktuális kérdései.] Semmelweis Kiadó, Budapest, 2011. [Hungarian]

[6] Jones JM, Lawson ML, Daneman D, et al. Eating disorders in adolescent females with and without type 1 diabetes: cross sectional study. Br Med J. 2000; 320: 1563-1566.

[7] Young V, Eiser C, Johnson B, et al. Eating problems in adolescents with type 1 diabetes: a systematic review with meta-analysis. Diabet Med. 2013; 30: 189-198.

[8] Pinhas-Hamiel O, Hamiel U, Levy-Shraga Y. Eating disorders in adolescents with type 1 diabetes: challenges in diagnosis and treatment. World J Diabetes 2015; 6: 517-526.

[9] Wisting L, Frøisland DH, Skrivarhaug T, et al. Disturbed eating behavior and omission of insulin in adolescents receiving intensified insulin treatment: a nationwide population-based study. Diabetes Care 2013; 36: 3382-3387.

[10] Bryden KS, Neil A, Mayou RA, et al. Eating habits, body weight, and insulin misuse. A longitudinal study of teenagers and young adults with type 1 diabetes. Diabetes Care 1999; 22: 19561960.

[11] Meltzer LJ, Johnson SB, Prine JM, et al. Disordered eating, body mass, and glycemic control in adolescents with type 1 diabetes. Diabetes Care 2001; 24: 678-682.

[12] Rodin GM, Daneman D. Eating disorders and IDDM. A problematic association. Diabetes Care 1992; 15: 1402-1412.

[13] Cserép M, Szumska I. Disordered eating among adolescents with chronic illnesses. [Evészavartünetek, problematikus evési magatartás egyes kamaszkori krónikus betegségekben.] Orv Hetil. 2020; 161: 1872-1876. [Hungarian]

[14] Takii M, Uchigata Y, Kishimoto J. The relationship between the age of onset of type 1 diabetes and the subsequent development of a severe eating disorder by female patients. Pediatr Diabetes $2011 ; 12: 396-401$

[15] Broadley MM, Zaremba N, Andrew B, et al. 25 Years of psychological research investigating disordered eating in people with diabetes: what have we learnt? Diabet Med. 2020; 37: 401-408.

[16] Ábrahám I, Jambrik M, John B, et al. Body image and body image distortion. [A testképtől a testképzavarig.] Orv Hetil. 2017; 158: 723-730. [Hungarian]

[17] Clery P, Stahl D, Ismail K, et al. Systematic review and metaanalysis of the efficacy of interventions for people with type 1 diabetes mellitus and disordered eating. Diabet Med. 2017; 34: $1667-1675$.

[18] Alexandridis G, Liamis G, Elisaf M. Reversible tubular dysfunction that mimicked Fanconi's syndrome in a patient with anorexia nervosa. Int J Eat Disord. 2001; 30: 227-230.

[19] Pászthy B, Ábrahám I, Törzsök-Sonnevend M. Hungarian clinical practice guideline for the treatment of eating disorders in childhood and adolescence. [Az Emberi Erőforrások Minisztériuma egészségügyi szakmai irányelve a gyermek- és serdülókori evészavarok ellátásáról.] Eü Közl. 2020; 70: 1174-1212. [Hungarian]

[20] Markowitz JT, Butler DA, Volkening LK, et al. Brief screening tool for disordered eating in diabetes: internal consistency and external validity in a contemporary sample of pediatric patients with type 1 diabetes. Diabetes Care 2010; 33: 495-500.

(Máté Orsolya,

Budapest, Bókay János u. 53-54., 1083

e-mail: mate.orsolya@med.semmelweis-univ.hu)

A cikk a Creative Commons Attribution 4.0 International License (https://creativecommons.org/licenses/by/4.0/) feltételei szerint publikált Open Access közlemény. (SID_1) 